315.5

A 34

1961

gr. 12

CURRGDHT 


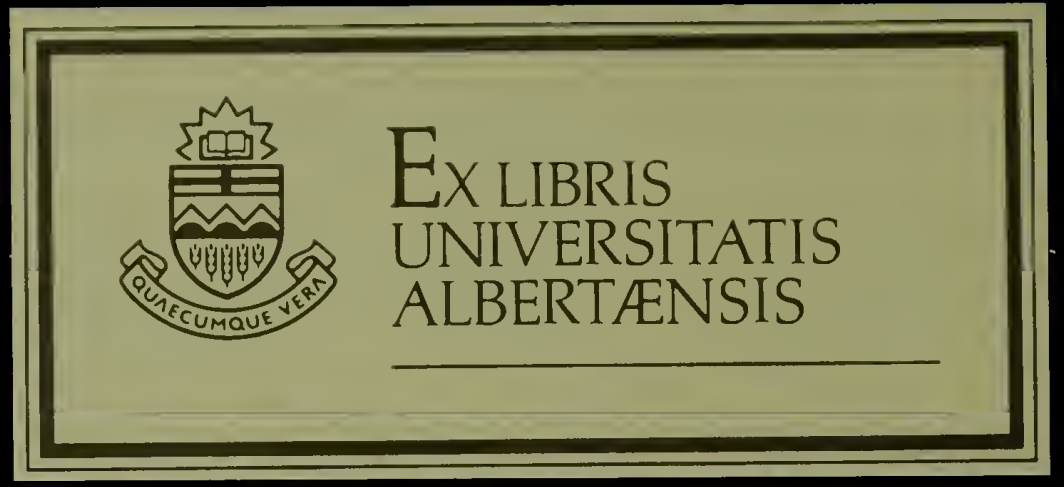


References

Primary Reference

BIOLOGY IN DAILY LIFE, Curtis and Urban

\section{Secondary References}

ELEMENTS OF BIOLOGY, Dodge, Smallwood, Reverley, Bailey

EXPLORING BIOLOGY, EIla Thea Smith

MODERI BIOLOGY, Moon, Man and Otto

A IABORATORY COURSE IN BIOLOGY, J. G. Rempel

\section{UNIT I - A SURVEY OF LIVING THINGS}

\section{Objectives}

1. To give pupils an overview of the field of biology.

2. To give pupils an awareness of the interdependence of living things.

3. To give the teacher an opportunity to ascertain the interests and aptitudes of the pupils.

4. To utilize the living things found abundantly in the community.

5. To enable the pupils to become acquainted with the living things in their locality.

\section{Generalizations}

1. All living things are interdependent with their living and physical environment.

2. The basic aspects of living - nutrition, protection, and reproduction are responsible for this interdependence.

3. Life exists wherever conditions such as food, water, oxygen, and certain limits of temperature and pressure are favorable.

4. Life, matter, and energy follow cycles involving change but no loss or creation.

5. The balance of nature is ever changing.

\section{$\underline{\text { References }}$}

BIOLOGY IN DAILY LIFE, pp. 17-57; 511-569

ELENENTS OF BIOLOGY, pp. $4-36$

EArLORIIVG BIOLOGY, pp. 5-112

MODERN BIOLOGY, pp. 53-86

\section{UNTT III - GREEN PLANTS NIAKE THE FOOD USED BY ALL LIVING THINGS}

\section{Objectives}

1. To give the pupils a functional understanding of the energy transformations in the green plant.

2. To acquaint pupils with the basic structure of plants. 
1. The sun is the source of all energy.

2. Green plants can transform the radiant energy of sunlight into chemical energy of foods.

3. Matter and energy cannot be created or destroyed. They can only be changed from one form into another.

4. The cell is the unit of structure of all living things.

5. The size and shape of cells vary according to function.

\section{$\underline{\text { References }}$}

BIOLOGY IN DAIIY LIFE, pp. 197-276

ELEMENTS OF BIOLOGY, pp. 293-348

EXPLORING BIOLOGY, pp. 201-216

MODERN BIOLOGY, pp. LLL-513

UNIT IV - FOODS AND METABOLISM

\section{Objectives}

1. To give pupils a functional understanding of the life processes involved in metabolism.

2. To give pupils an awareness of the important factors of a well-balanced diet.

3. To create an appreciation of the value of good health habits for the prevention of organic disorders.

\section{Generalizations}

1. There is a constant building up and tearing down within the body of every living organism.

2. All organisms transform energy of foods into other energy such as chemical, heat, mechanical energy.

3. The health of an individual depends upon the wise selection of foods.

4. All organisms have adaptations for getting food.

5. All organisms have means of converting food into soluble form.

6. Food and oxygen must be made available to all parts of every organism.

7. The toxins which are constantly being formed as a result of metabolism must be eliminated from the organism.

8. Cells have the ability to select from their environment those substances with which they carry out their particular function.

9. All plants and animals are basically alike.

10. The more complex the organism the more complex its structures for carrying out each metabolic process.

\section{References}

BIOLOGY IN DAILY LIFE, pp. 197-276

ELEIVENTS OF BIOLOGY, pp. 293-348

EXPLORING BIOLOGY, pp. 201-216

MODERN BIOLOGY, pp. $444-513$ 



\section{UNIT V - THE CONQUEST OF DISEASE}

\section{Objectives}

1. To give pupils an understanding of the causes and nature of important germ and non-germ diseases.

2. To give pupils an understanding of the body's natural defences against disease.

3. To give pupils an appreciation of the contribution of scientists to the conservation of human life through the prevention and treatment of diseases.

\section{Generalizations}

1. All living things are subject to diseases.

2. Some diseases of plants and animals are caused by parasites; others are caused by dietary deficiencies; others are caused by glandular unbalance; and others by allergies and wearing out of organs.

3. Living things, by their life activities, affect the welfare of other living things.

4. Every kind of plant and animal has enemies, and only those that are able to avoid or resist the attacks of enemies live long enough to produce offspring.

5. Parasitism results from the struggle for survival.

6. Some parasites require more than one host in order to complete their life cycles.

7. Each germ disease is caused by a specific parasite.

8. The bodies of organisms have various natural deferces against attacks by micro-organisms.

9. We can conserve human life by the application of scientific knowledge to prevention and treatment of disease.

\section{References}

BIOLOGY IN DAILY LIFE, pp. 277-354

ELEMEINTS OF BIOLOGY, Pp. 389-410

EXPLORING BIOLOGY, pp. $245-316$

MODIRN BIOLOGY, pp. 559-606

\section{UNIT VI - THE BEHAVIOR OF LIVING THINGS}

\section{Objectives}

1. To give pupils the basic concepts necessary for understanding plant and animal behavior.

2. To give pupils an appreciation of their own nervous system.

3. To give pupils the understanding that behavior usually has definite causative factors and that man must study these causative factors in an effort to understand and control his own behavior.

Generalizations

1. All living things react to stimuli.

2. Successful reactions make it possible for the organism to obtain its basic needs. 

3. Most organisms are of such complexity that they need specialized structures to govern behavior.

4. Man's nervous system assures him of top place in the world of life.

5. Man's behavior is determined by his general physical condition, by his rate of growth, by his chemical balance, and by his nervous system.

6. in individual's behavior is limited by his heredity and greatly affected by his environment.

7. The character of the response is often determined by the efficiency of the sense organs.

8. Man can increase his efficiency by conditioning his behavior.

\section{$\underline{\text { References }}$}

BIOLOGY IN DAILY LIFE, pp. 355-427

ELEMENTS OF BIOLOGY, pp. 349-376

EXPLORING BIOLOGY, pp. $317-360$

MODERN BIOLOGY, pp. 514-534; 499-507

\section{UNIT VII - REPRODUCTION OF IIVING THINGS}

\section{Objectives}

1. To develop an understanding of the beginnings of life.

2. To learn the differences and similarities in the reproductive processes of plants and animals.

3. To learn something of the way nature has provided for the care of the young.

4. To study the elementary embryology of a few typical plants and animals.

\section{Generalizations}

1. Reproduction is a universal and natural process in the biological world.

2. Reproduction is fundamentally the separating-off of a part of an organism to make another like itself.

3. A great variety of adaptations aid in the reproductive process.

4. Some plants and animals employ sexual methods, some asexual and some both. Sexual reproduction may occur in all but the lowest plants and animals.

5. Sexual reproduction involves fertilization.

6. Development from zygote to complex organism proceeds in regular and definite fashion very similar in all organisms.

7. Sex glands produce hormones as well as reproductive cells.

8. Number of offspring is in adverse proportion to the amount of parental care.

\section{$\underline{\text { References }}$}

BIOLOGY IN DAILY LIFE, pp. 428-464

ELEMENTS OF BIOLOGY, pp. 570-573

EXPLOR ING BIOLOGY, pp. 361-422

MODERN BIOLOGY, pp. 170-195 

UNIT VIII - VARIATION AND HEREDITY

\section{Objectives}

1. To develop some understanding of the succession of living things through the ages.

2. To develop an understanding of the role of heredity in one's orm environment.

3. To gain a knowledge of the units that carry the characteristics from parents to offspring.

4. To learn how the laws of heredity may be applied to plant and animal breeding and to the improvement of the human race.

5. To develop interest associated with the care of plants and animals.

\section{Generalizations}

1. Records of life of past ages are obtained from the study of fossils.

2. The fossil evidence indicates that the kinds of plants and animals that inhabited the earth change in form and structure over long periods of time.

3. Every expressed character in an individual is the product of the interaction of genetic and environmental factors.

4. Variation is a universal phenomenon among living things.

5. Characters are usually inherited as units and are determined by genes carried in the chromosomes.

6. Evolution is a process consisting largely of the chance formation of new heredity factors and their loss or increase in frequency within a population.

7. Knowledge of the mechanism of heredity has made it possible to use a system of trial and error, and dependable prediction, in the production of new, more useful varieties of plants and animals.

8. The difference between one race and another is usually not a matter of the possession by one or another of certain unique characters.

9. Chromosomes may be altered by environmental factors so that mutations appear which suddenly show significant changes in form or character in one or more heritable characteristics in a single generation.

10. Success in the breeding of new and of more useful domesticated plants and animals rests upon knowledge of the mode of the inheritance of specific traits.

\section{$\underline{\text { References }}$}

BIOLOGY IN D..ILY LIFE, pp. 465-509

ELEMENTS OF BIOLOGY, pp. 575-588; 604-632

EXPLORING BIOLOGY, pp. 423-50L

MODERN BIOLOGY, pp. 607-668 



\section{UNIT IX - THE KINDS OF LIVING THINGS}

(Some teachers may prefer to take this Unit immediately after Unit I or to disperse it among the other units.)

Objectives

1. To give the pupils an understanding of the important characteristics of the great groups of plants and animals.

2. To give pupils an understanding of the relationship of the great groups of plants and animals to one another.

\section{Generalizations}

1. Animals can be divided into about ten phyla, all the members of each having certain characteristics in common.

2. The vertebrate sub-phylum can be divided into several classes, the members o? each class having certain unique characteristics.

3. Plants can be divided into four phyla, each of which is subdivided into classes.

4. The higher forms of life are more complex in structure. This increase in complexity of structure is accompanied by an increase in division of labor.

References

BIOLOGI IN DAILY LIFE, pp。513-569

EIENENIS OF BIOLOGY, pp. 589-603

EXFIOR ING BIOLOGY, pp. 27-112

MODERN BIOLOGY, $\mathrm{pp} .219-424$ 


\section{DATE DUE SLIP}

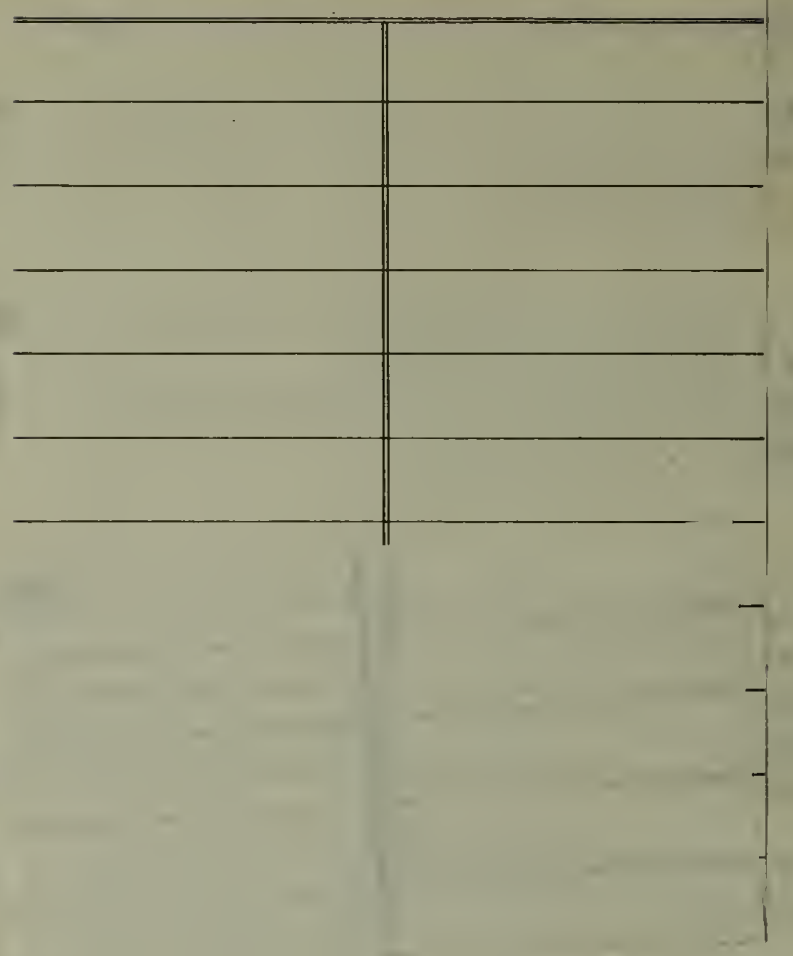


OH $315-5 \quad A 34 \quad 1961 \quad G R-12$

BIOLOGY $32 \ldots$

NL 40049183 CURR HISI
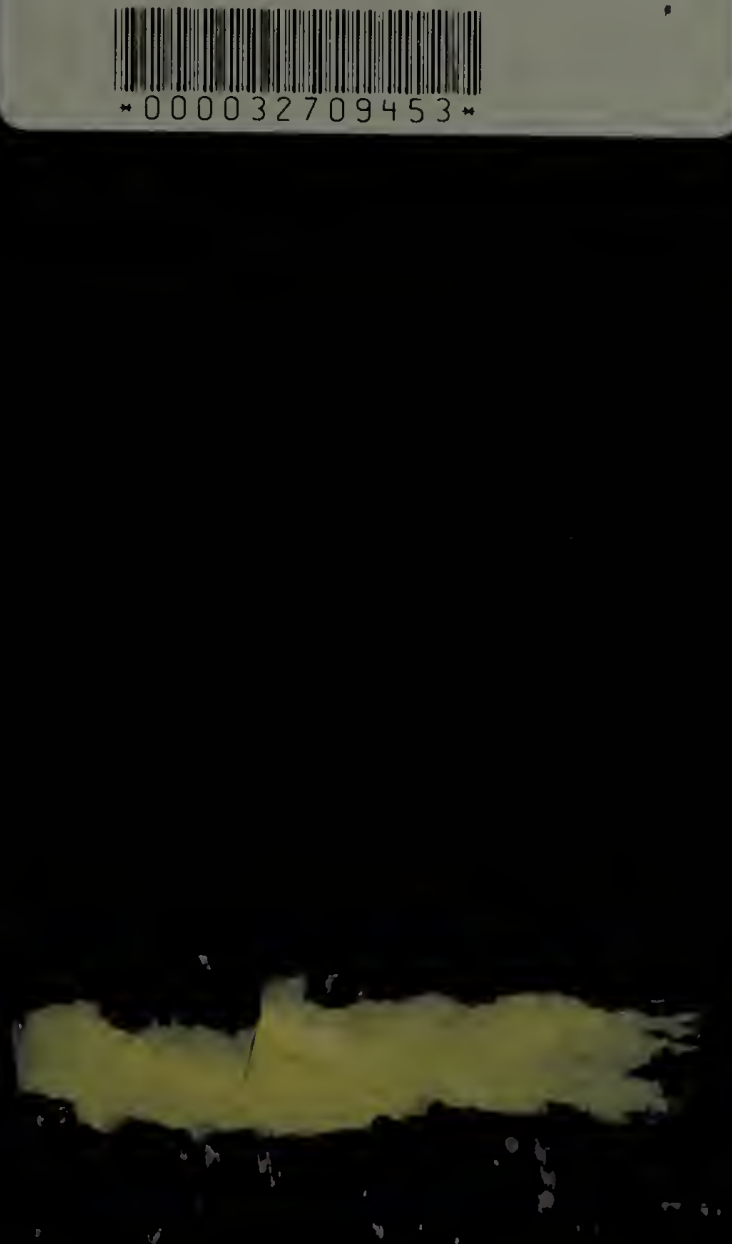

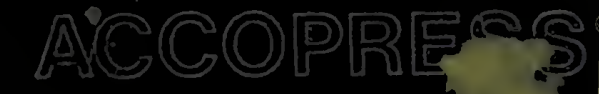

250. $N$ BLACK/NOIR

$250 \%$ - RED/ROUGE

250 - GREEN FVERT - TP2

$250^{\circ} 4$ - GREY/GRIS, - BOP

250 3. - R. BLUE/BLEUR. - BBZwU?

25079 - X.RED/ROLGEX. BX B

25079 - YELLOW/ JAUNE BYS.507.

2507 - TANC RINE - BATOT

ACSO- CANADIAN COMPÁNY LIMITED

COMPAGNIE CANADIENNE ACCO LIMPTEE

TORONTO CANABA 
